\title{
CFD Modeling and Experimental Validation of a Solar Still
}

\author{
Tahir Mahmood ${ }^{1}$, Muhammad Y. Naz ${ }^{1}$, Shaharin A. Sulaiman ${ }^{2 *}$, Yasir Jamil ${ }^{1}$, Shazia \\ Shukrullah ${ }^{1}$, Muhammad Zahid ${ }^{3}$, Muddasser Inayat ${ }^{2}$ \\ ${ }^{1}$ Department of Physics, University of Agriculture, 38040 Faisalabad, Pakistan. \\ ${ }^{2}$ Department of Mechanical Engineering, Universiti Teknologi Petronas, 32610 Bandar Seri Iskandar, \\ Perak, Malaysia. \\ ${ }^{3}$ Department of Chemistry, University of Agriculture, 38040 Faisalabad, Pakistan.
}

\begin{abstract}
Earth is the densest planet of the solar system with total area of 510.072 million square $\mathrm{Km}$. Over $71.68 \%$ of this area is covered with water leaving a scant area of $28.32 \%$ for human to inhabit. The fresh water accounts for only $2.5 \%$ of the total volume and the rest is the brackish water. Presently, the world is facing chief problem of lack of potable water. This issue can be addressed by converting brackish water into potable through a solar distillation process and solar still is specially assigned for this purpose. Efficiency of a solar still explicitly depends on its design parameters, such as wall material, chamber depth, width and slope of the zcondensing surface. This study was aimed at investigating the solar still parameters using CFD modeling and experimental validation. The simulation data of ANSYS-FLUENT was compared with actual experimental data. A close agreement among the simulated and experimental results was seen in the presented work. It reveals that ANSYS-FLUENT is a potent tool to analyse the efficiency of the new designs of the solar distillation systems.
\end{abstract}

\section{Introduction}

Population of the world, especially in developing countries, is increasing exponentially and so does the consumption of potable water. The water is the most important in the contents of fundamental needs for the survival of living organisms [1]. Over $71.68 \%$ of the total area of earth is covered with water leaving a scant area of $28.32 \%$ for human to inhabit. Out of this total volume of water on the earth, the fresh water accounts for only $2.5 \%$ and the rest is the brackish water. Adding more, only $0.3 \%$ of the fresh water exists in liquid form. Since water is not used efficiently by the world, the sources of drinkable water are depleting with every passing moment. Other than the use for food and fiber by the human, many economic, technological and political factors are also intensifying the water shortage upto an alarming

\footnotetext{
* Corresponding author: shaharin@utp.edu.my
} 
level. Therefore, the requirement of this age is to develop selfsustained systems to distill the available saline water into drinkable water for the better health of human being.

The countries like Pakistan, India, Bangladesh and African nations accommodate the notable part of the world population [2]. These countries also face high intensity of the solar radiations throughout the year. The issue of potable water shortage in such countries can be fairly reduced by processing brackish water with solar distillation systems [3, 4]. For converting saline water into potable water, solar still technology regarded as a low cost, simple and easily adaptable. Since solar still does not involve any specialty items in its fabrication, it is easy to maintenance and fabricate with locally available materials. A solar still works on the principle of evaporation and condensation due to a difference in temperatures of front glass-cover and the water in the basin. Solar still absorbs the solar radiations, falling on the front glass-cover, to raise the temperature of the impure water. The hot water evaporates and then condenses on the lower surface of the glass cover by leaving all the contaminants in the basin [4]. However, the evaporation-condensation in such systems is an essential assignment to raise the production rate of the fresh water. Therefore, to assess the efficiency of a solar still design, not only the experimental work but the development of suitable mathematical models investigating the different parameters of the solar still, are inevitably required.

Numerous research findings, addressing the effects of different factors on the solar still productivity, have been reported in the past literature. Tiwari et al. [3] considered inner glass temperature in performing the computer modeling of a passive/active solar still. They found that the solar still with cover-glass inclination angle of $30^{\circ}$ is suitable for production of fresh water at reasonably good rates. Maximum heat transfer from the sun to the water was reported at this inclination angle. Work of Tiwari and Tripathi [4] showed that the semi-cylindrical shape of the solar distillation units is far better than the spherical geometry. It was also reported that the fresh water flows at higher rates during forced convection than that of natural convection. As a best factor that enhances the solar still productivity, Omar et al. [5] worked out at an active solar single slope at different functional parameters, such as variation in insulation thickness, effective transmissivity, effective absorptivity and solar intensity. Shakaib et al. [6] tested the effectiveness of a solar still and revealed that the efficiency of a solar still dependent on the fluid flow patterns during forced convection of the moist air. They carried out CFD analysis of a solar still and presented the results in terms of velocity and temperature profiles, distribution of shear stress and heat transfer coefficient. Their work revealed major flow recirculation within the solar still, which might be a useful parameter for increasing the rate of production of fresh water. Panchal et al. [7] investigated that all parameters of a solar still like chamber temperature, glass-cover temperature, vapor temperature, basin water temperature, etc. are directly proportional to the distillate output. The simulation results of their work showed a good agreement with experimental data.

This study is based on experimental and computational approaches to test a solar distillation system by comparing the experimental data and ANSYS-FLUENT simulation results. The properties of the fresh water, obtained with the single slope solar still design, are also tested to check the product quality and the process efficiency.

\section{Methodology}

Geometry of a single slope solar still design is shown schematically in Fig. 1. On experimental side, the solar distillation system was consisted of a wooden box with square base, rectangular top glass-cover and a metal tray sheet. The top surface of the solar still was covered with a $2 \mathrm{~mm}$ thick glass sheet. The metal try sheet of $3 \mathrm{~mm}$ thickness was used to raise the solar intensity and a wooden box to minimalize the heat losses from the system. The inclination angle of the glass-cover was fixed to $20^{\circ}$. Evaporation and condensation of 
brackish water taken place when the setup was exposed to direct sunlight. The experiments were performed in the main campus of the University of Agriculture Faisalabad, Pakistan during July 2017. Temperature of the glass cover, basin water and outlet water was measured after every hour starting from 9:00 am to 17:00 pm. The most favorable evaporationcondensation was attained at noon from 12:00 pm to 15:00 pm. The properties of the distilled water, obtained with the single slope solar still design, were tested to check its quality.

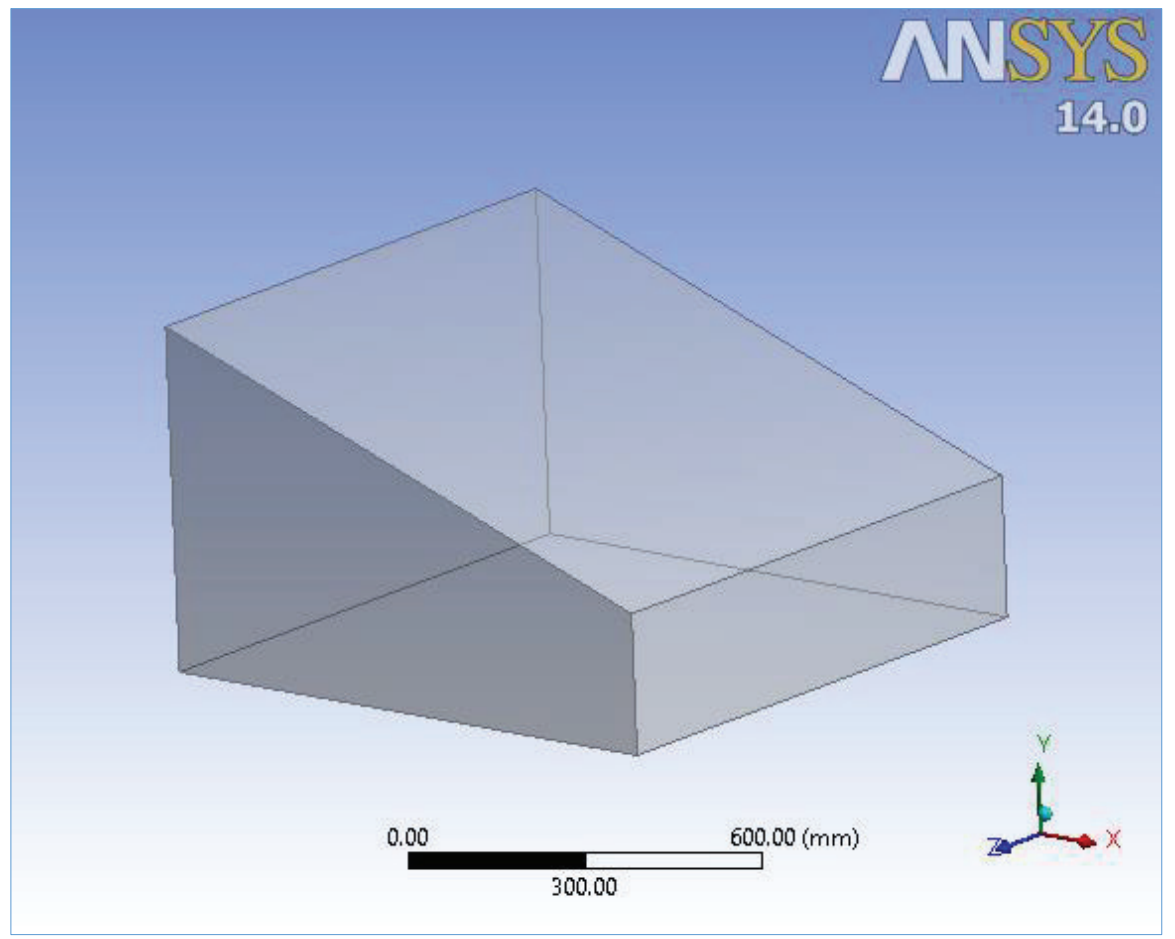

Fig. 1. Geometry of a single slope solar still design.

For ANSYS CFD modeling of the solar still, a 3-D model was made in ANSYSFLUENT workbench design modeler which is an abelian software package in ANSYS CFD. The model had six faces, which were considered as waterproof walls. The temperature of the bottom and top surfaces was fixed at $293 \mathrm{~K}$ and $403 \mathrm{~K}$, respectively. The remaining walls were assumed adiabatic. The height of the front and back walls of the unitary cubical solar still was $250 \mathrm{~mm}$ and $610 \mathrm{~mm}$, respectively, which inclined the top surface slope (glasscover) at $20^{\circ}$. The width and depth of the unit were fixed at $1 \mathrm{~m}$. Fig. 2 shows the fine cell meshing of the solar still geometry. ANSYS FLUENT 14.0 was used to solve the equations of continuity, momentum and energy for the meshed geometry. Air is an ideal fluid because its thermal conductivity and viscosity varies with temperature. Therefore, the Rayleigh number for the simulation was set 1200 . First order upwind scheme was used to discretize the convective terms while SIMPLE algorithm was used to couple the temperature and velocity profiles. 

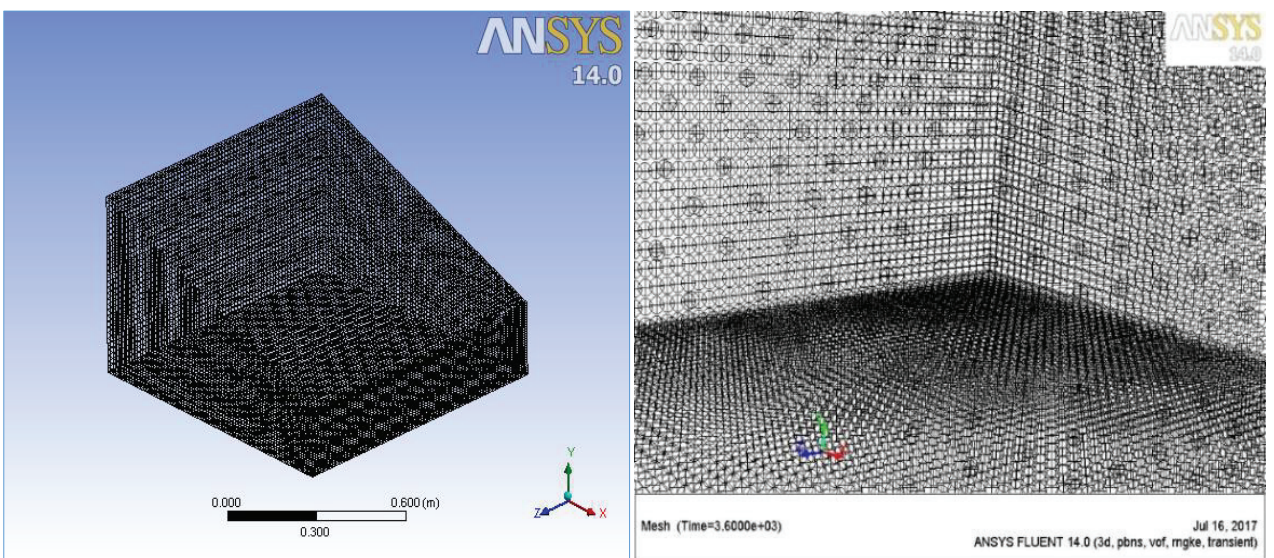

Fig. 2. Meshing of the solar still geometry for CFD simulation.

\section{Result and Discussion}

Temperature of the glass cover, basin water and outlet water was measured after every hour starting from 9:00 am to 17:00 pm, as shown in Table 1. The most favorable evaporation-condensation rates were attained at noon from 12:00 pm to 15:00 pm.

Table 1. Experimental data extracted from the solar still prototype.

\begin{tabular}{|c|c|c|c|c|c|}
\hline Time & $\begin{array}{c}\text { Collected } \\
\text { water } \\
(\mathbf{m l})\end{array}$ & $\begin{array}{c}\text { Inlet } \\
\text { temperature } \\
\left({ }^{\mathbf{}} \mathbf{C}\right)\end{array}$ & $\begin{array}{c}\text { Outlet } \\
\text { temperature } \\
\left({ }^{\circ} \mathbf{C}\right)\end{array}$ & $\begin{array}{c}\text { Basin } \\
\text { temperature } \\
\left({ }^{\mathbf{O}} \mathbf{C}\right)\end{array}$ & $\begin{array}{c}\text { Glass cover } \\
\text { temperature } \\
\left({ }^{\circ} \mathbf{C}\right)\end{array}$ \\
\hline 09:00 to $10: 00$ & 35 & 34 & 36 & 40 & 33 \\
\hline 10:00 to $11: 00$ & 50 & 34 & 37 & 45 & 36 \\
\hline 11:00 to $12: 00$ & 95 & 34 & 40 & 45 & 36 \\
\hline 12:00 to $13: 00$ & 185 & 34 & 41 & 48 & 38 \\
\hline 13:00 to $14: 00$ & 200 & 34 & 42 & 52 & 40 \\
\hline 14:00 to $15: 00$ & 180 & 34 & 41 & 49 & 38 \\
\hline 15:00 to $16: 00$ & 145 & 34 & 40 & 49 & 37 \\
\hline 16:00 to $17: 00$ & 115 & 34 & 36 & 45 & 36 \\
\hline
\end{tabular}

The flow patterns in the solar still are shown in Fig. 3 with the help of velocity contour and path-lines on its all faces. On the front and back surface, the velocities were lower and this flow behavior can be considered suitable because the recirculating air would possibly drive the condensed water towards the distillate tray of the solar still.

The temperature contours in Fig. 4a shows variation of temperature in the vertical direction. Due to fixed temperatures of the top and bottom surfaces, the temperature variations were rapid near the front vertical wall of shorter height [7]. The enthalpy of the water was also higher at the front wall and in the center of the glass and absorber plate, as shown in Fig. 4b. The heat transfer coefficient was found to be higher near the vertical wall with shorter height due to higher temperature gradients, as shown in Fig. 5 


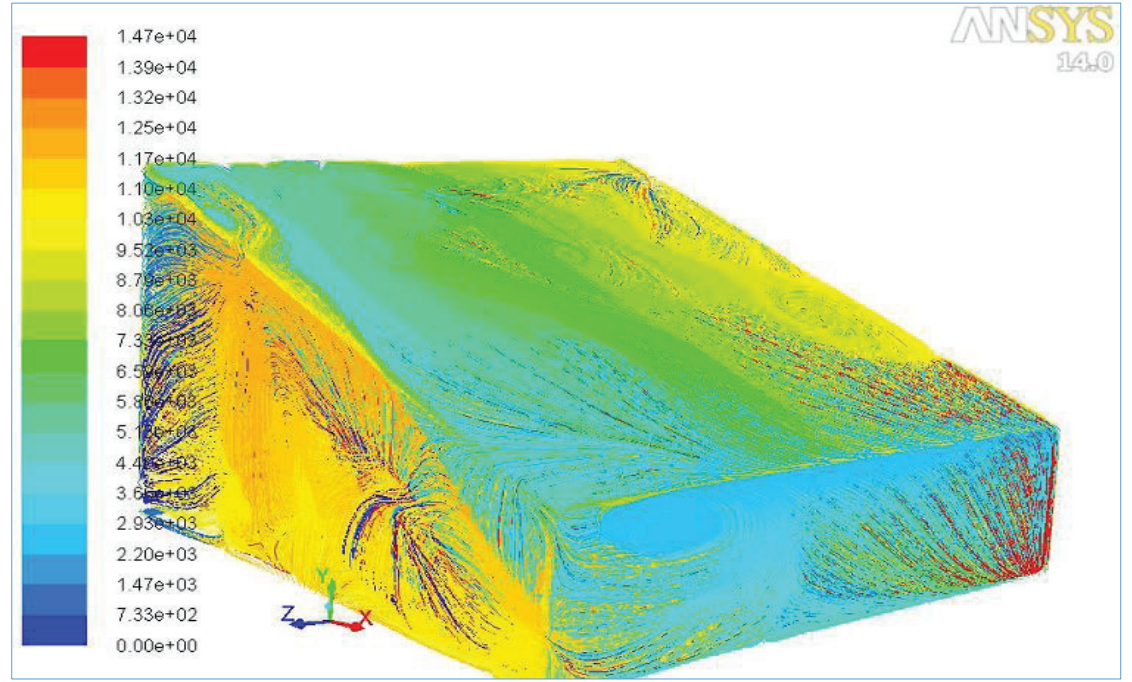

Fig. 3: Velocity path-line contour in the solar still.

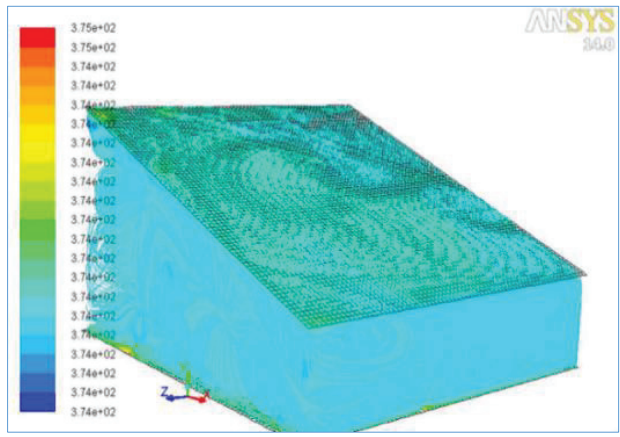

(4a)

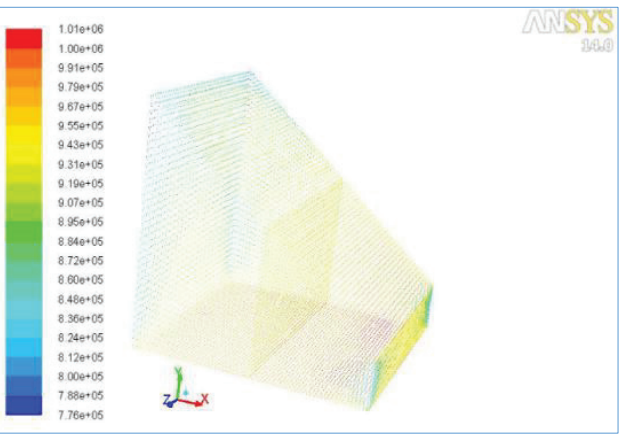

(4b)

Fig. 4. (4a) Temperature profiles at top and bottom surfaces, (4b) enthalpy of water $(\mathrm{J} / \mathrm{Kg})$.

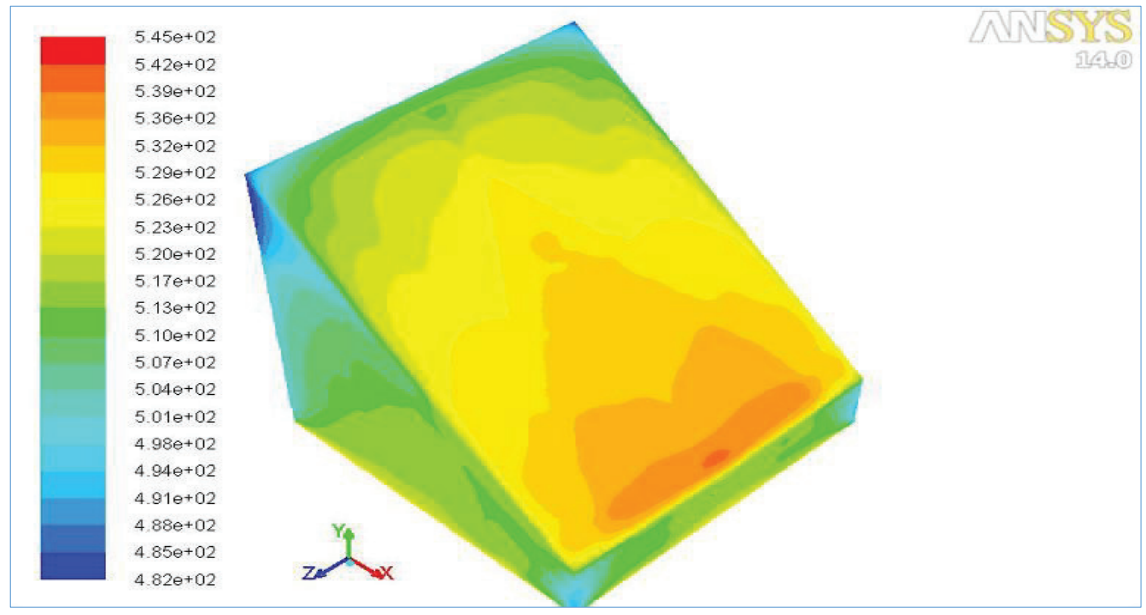

Fig. 5. Heat transfer coefficient. 
Experimental and simulation results were compared by following the Dunkle correlation:

In this equation:

$$
\mathrm{Nu}=0.075 \mathrm{Ra}^{1 / 3}
$$

$$
\begin{gathered}
\mathrm{Nu}=\frac{\mathrm{h}_{\mathrm{av}} \mathrm{L}_{\mathrm{c}}}{\mathrm{k}} \\
\mathrm{Ra}=\frac{\mathrm{g} \beta\left(\mathrm{T}_{\mathrm{w}}-\mathrm{T}_{\infty}\right) \mathrm{L}_{\mathrm{c}}^{3}}{\mathrm{v}^{2}} \mathrm{p}_{\mathrm{r}}
\end{gathered}
$$

Where $\mathrm{Nu}$ is the Nusselt number, Lc is the average height of the unit, Pr is the Prandtl number and $\mathrm{Ra}$ is the Rayleigh number. Fig. 6 provides a comparison of the experimental and ANSYS FLUENT data. A close agreement among the production rates of the potable water from the actual experiment and the simulation was predicted in the presented work.

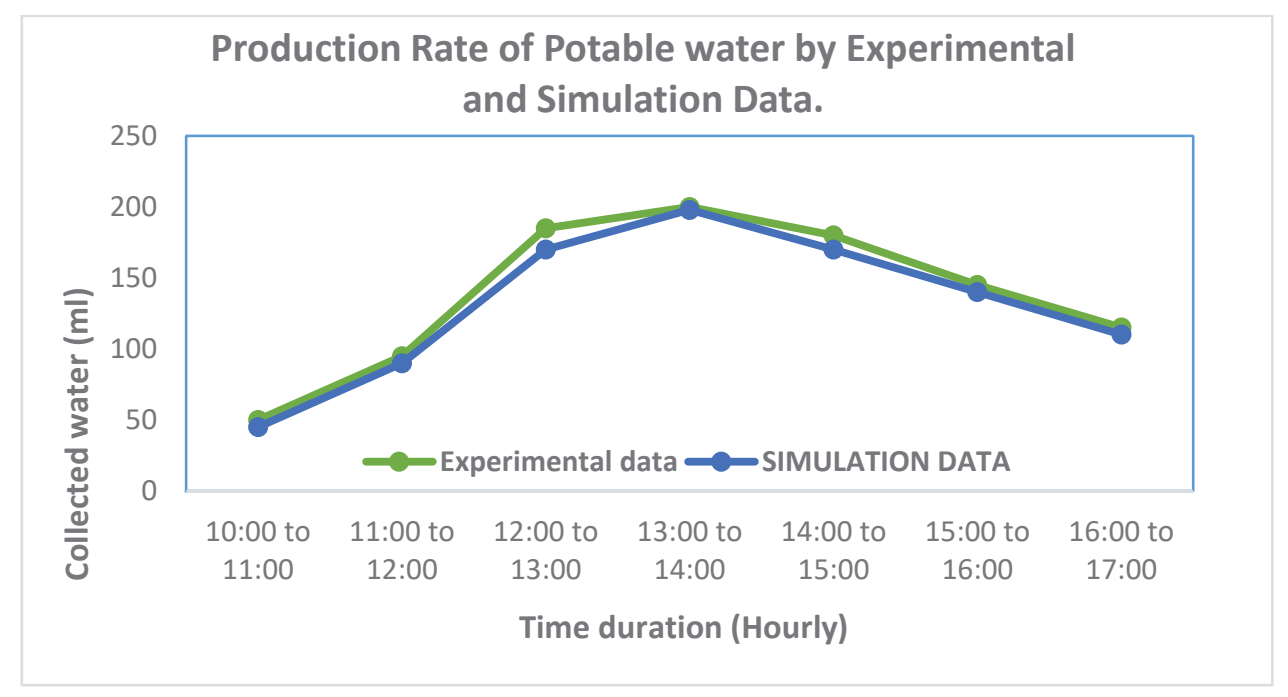

Fig. 6: Production rates of potable water from experiment and simulation.

\section{Conclusion}

To produce distillate output, the evaporation and condensation in a solar still need to happen at reasonably good rates. The simulation data showed lower velocities at the front and back surfaces and such flow behaviors are generally desired for high performance solar stills. The presented study revealed a close agreement among the simulation and experimental data, showing that the performance evaluation of a solar still is pretty simple with ANSYSFLUENT.

\section{References}

1. Y. Arjen Hoekstra, M. M. Mekonnen. PAS, USA 109,3232-3237 (2012)

2. P. Micklin, AREPS 35, 47-72 (2007)

3. G. N. Tiwari., S.K. Shukla, I.P. Singh, JECM 154, 171 (2003)

4. G. N. Tiwari, R. Tripathi, JECM 154, 161-169 (2003)

5. M. Shakaib, M. A. Khan, ICMAEE-15, pp. 272-276 (2015)

6. H. N. Panchal, N. Patel, IJAE (2017)

7. N. S. Gokilavani, D. Prabhakaran, T. Kannadasan, IJIRSET 3, (2014) 